\title{
Evaluation of Lamivudine Resistance Assay Using a Molecular Method in Patients with Chronic Hepatitis B
}

\section{Kronik Hepatit B Hastalarında Moleküler Metod ile Lamivudin Direnç Analizinin Değerlendirilmesi}

\author{
Şükran KÖSE, Melda TÜRKEN, Selma GÜL \\ Izmir Tepecik Education and Research Hospital, Clinic of Infectious Diseases and Clinical Microbiology, Izmir, Turkey
}

\begin{abstract}
Objective: Lamivudine is a nucleoside analogue approved by the FDA in 1998 for the treatment of chronic hepatitis B. Its unique disadvantage compared to other antiviral agents used in hepatitis $B$ treatment is the emergence of drug resistance during treatment. In this study, we aimed to determine lamivudine resistant mutations.

Materials and Methods: The results of Lamivudine resistance assay were studied in 172 patients with chronic hepatitis B applying to Izmir Tepecik Training and Research Hospital between December 2007 and January 2010. The assay was studied by Multiplex PCR and Reverse Hybridization methods at Izmir Tepecik Education and Research Hospital Infectious Diseases and Clinical Microbiology Laboratory. In our laboratory, RT204, RT180, RT173, and RT80 parameters were searched as resistance parameters.

Results: Out of 172 chronic hepatitis B patients, post-treatment lamivudine resistance was found to be positive in 43 patients and negative in 45 patients. Resistance assays were determined to be negative in 82 patients without lamivudine use, and positive in two patients. In this study, the most frequent association was determined to be between rtM204V and rtL180M (8.13\%). The second most frequent association was rtM204I and rtL180M with rtL80V $(4.65 \%)$, and the third most frequent association was found to be between rtM204l and rtL80V mutations (4.06\%).

Conclusion: Resistance development due to lamivudine used in chronic hepatitis B treatment happens through genes encoding reverse transcriptase enzyme. The most commonly detected mutations are RT 204 and RT 180 mutations. The development of lamivudine resistance limits the use of the drug.
\end{abstract}

Key Words: Lamivudine, resistance, chronic hepatitis B

Conflict of interest: The authors reported no conflict of interest related to this article.

\section{ÖZET}

Amaç: Kronik hepatit B tedavisinde nükleoz(t)id analogları ve interferon kullanılmaktadır. Lamivudin, 1998 yılında kronik HBV tedavisinde ruhsat alarak kullanıma girmiş olan ilk L-nükleozid analogudur. Diğer antivirallerden dezavantajı, hepatit B tedavisi sırasında oluşan ilaç direncidir. Bu çalışmada lamivudin direnç mutasyonlarının belirlenmesini amaçladık.

Gereç ve Yöntemler: Izmir Tepecik Eğitim ve Araştırma Hastanesi Enfeksiyon Hastalıkları ve Klinik Mikrobiyoloji laboratuvarına 2007 Aralık-2010 Ocak tarihleri arasında, kronik hepatit B nedeniyle başvuran 172 hastanın lamivudin direnç test sonuçları Multipleks PCR ve Ters Hibridizasyon yöntemleriyle incelendi. Laboratuvarımızda lamivudin direnç paterni olarak RT 204, RT180, RT173, RT 80 parametreleri bakıldı.

Bulgular: Toplam 172 kronik hepatit B hastasından 43 hastada lamivudin tedavi sonrası direnç testleri pozitif, 45 hastada lamivudin tedavi sonrası direnç testleri negatif saptandı. Lamivudin kullanımı olmayan 82 hastada direnç testleri negatif, 2 hastada direnç testleri pozitif saptandı. Bu çalışmada en sık \%8,13 ile rtM204V ve rtL180M mutasyon birlikteliği saptandı. En sık ikinci mutasyon \%4,65 ile rtM204I, rtL180M ve rtL80V birlikteliği, üçüncü olarak \%4,06 ile rtM204l ve rtL80V mutasyon birlikteliği saptandı.

Sonuç: Kronik hepatit B tedavisinde kullanılan lamivudine bağlı direnç gelişimi ters transkriptaz enzimi kodlayan genler yoluyla gerçekleşir. En sık tespit edilen mutasyonlar rtM204I ve rtL180M mutasyonlarıdır. Lamivudin direnci gelişimi ilacın kullanımını sınırlamaktadır.

Anahtar Kelimeler: Lamivudin, direnç, kronik hepatit B

Çıkar çatışması: Yazarlar bu makale ile ilgili olarak herhangi bir çıkar çatışması bildirmemişlerdir. 


\section{Introduction}

Chronic hepatitis $\mathrm{B}(\mathrm{CHB})$ is an important health issue and one of the most common infectious diseases affecting nearly 400 million people worldwide. According to the World Health Organization data, one third of the world's population has been infected with hepatitis B virus (HBV) and 5\% of the world's population are chronic carriers. About one fourth of these chronic patients will ultimately develop liver cirrhosis or liver cancer which are both fatal liver diseases $(1,2)$. Nucleos(t)ide analogues and interferon are administered during the treatment of chronic hepatitis B. Lamivudine, which was approved by the United States Food and Drug Administration (FDA) in 1998, is the first $\mathrm{L}$-nucleoside analogue to come on the market for the treatment of $\mathrm{CHB}$. Lamivudine is effective in $\mathrm{HBeAg}$-positive and negative patients with chronic HBV infections, in patients with either compensated or decompensated cirrhosis and in the treatment of chronic HBV infections in children. The resistance developing against this drug in patients using lamivudine constitutes the most important problem in $\mathrm{CHB}$ treatment. Mutations in $\mathrm{C}$ and $\mathrm{B}$ regions on reverse transcriptase polymerase gene are the main mutations responsible for lamivudine resistance (3). In this study, we aimed to determine lamivudine resistance mutations in $\mathrm{CHB}$ patients admitted to our hospital.

\section{Materials and Methods}

Lamivudine resistance assay was studied in 172 patients with $\mathrm{CHB}$ admitted to Izmir Tepecik Training and Research Hospital between December 2007 and January 2010. The assay was studied by Multiplex PCR-Reverse Hybridization methods (Inno-Lipa HBV DR v2. Innogenetics, Belgium) at Izmir Tepecik Education and Research Hospital Infectious Diseases and Clinical Microbiology Laboratory. In our laboratory, RT204, RT180, RT173, and RT80 parameters were searched as resistance parameters.

\section{Results}

Out of $172 \mathrm{CHB}$ patients, post-treatment lamivudine resistance was found to be positive in 43 patients and negative in 45 patients. Resistance assays revealed negative results in 82 patients without lamivudine use, and positive in two patients. In this study, the most frequent mutation was the existence of both rtM204V and rtL180M mutations together with the rate of $8.13 \%$. The second most frequent mutation was the existence of rtM204I, rtL180M, and rtL80V together with the rate of $4.65 \%$. The third most frequent mutation was the existence of rtM204I and rtL80V mutations together with the rate of $4.06 \%$. Lamivudine resistance rates are shown in Table 1.

\section{Discussion}

The use of antiviral drugs in the treatment of chronic HBV infections began at the end of 1990s. Until now, in an experience of 10-12 years, the use of antivirals, mainly lamivudine, has been a matter of debate. In the light of this experience, it is demonstrated that long-term lamivudine use is associated with high rates of $\mathrm{HBeAg}$ seroconversion and HBV-DNA loss. However, long-term administration results in mutant virus infections resistant to the drug (3).
HBV polymerase has reverse transcriptase activity and the mutations formed in catalytic part of this activity (YMDD motif) may cause resistance to lamivudine which is commonly used in both adult and pediatric CHB patients. In this aspect, mutations are frequently encountered in this catalytic part in patients receiving long-term lamivudine therapy. When YMDD motif is examined, it is observed that methionine is substituted for valine or isoleucine and transformed to YVDD or YIDD. Other compensatory mutations in HBV polymerase region accompany these changes (rtL80V/l, rtV173L). To date, lamivudine has developed five different resistance patterns: rtM204I, rtL180M + rtM204V, rtL180M + rtM204V, rtV173L + rtL180M + rtM204V, rtL80V/I + rtL180M + rtM204I (4).

In this study, the most frequent mutation was the existence of both rtM204V and rtL180M mutations together with the rate of $8.13 \%$. The second most frequent mutation was the existence of rtM204I, rtL180M, and rtL80V together with the rate of $4.65 \%$. The third most frequent mutation was the existence of rtM204I and rtL80V mutations together with the rate of $4.06 \%$.

In various studies, the mutation leading to drug resistance as well as to decreased viral replication was found to be rtM204I/N mutation $(2,3,4,5)$. Our results were also found to be consistent with these studies.

Lamivudine drug resistance $2.38 \%$ was determined in 2 (2.38\%) of 84 patients not receiving lamivudine ErtM204l, rtL80I, rtL180M mutation combination was found in one and rtM204l, rtL180M, rtV173L, and rtL80I mutation combination in the other.

Independently from external interventions such as drug treatment, HBV variants have been detected spontaneously in some patients. Especially in patients not receiving drug treatment, mutants with lamivudine resistance have been reported in ratios varying between $1 \%$ and $27 \%(6,7,8,9)$.

Table 1. Lamivudine resistance ratios in all patients with chronic HBV

\begin{tabular}{|l|l|l|}
\hline Lamivudine Resistance & Number & Percentage \\
\hline rtM204V & 1 & 0.58 \\
\hline rtM204I & 2 & 1.16 \\
\hline rtM204V + rtM204I & 1 & 0.58 \\
\hline rtM204V + rtL180M & 14 & 8.13 \\
\hline rtM204V + rtL80V + rtL180M & 1 & 0.58 \\
\hline rtM204V + rtL180M + rtV173L & 2 & 1.16 \\
\hline rtM204V + rtV173L + rtL80V & 1 & 0.58 \\
\hline rtM204I + rtL180M + rtL80V & 8 & 4.65 \\
\hline rtM204I + rtL180M & 1 & 0.58 \\
\hline rtM204I + rtL80V & 7 & 4.06 \\
\hline rtM204I + rtL180M & 1 & 0.58 \\
\hline rtM204I + rtV173L + rtL80V +rtL180M & 1 & 0.58 \\
\hline rtM204V + rtM204I + rtL180M & 3 & 1.74 \\
\hline rtM204V + rtM204I + rtL180M + rtL80V & 1 & 0.58 \\
\hline rtM204V + rtM204I + rtV173L + rtL180M & 1 & 0.58 \\
\hline
\end{tabular}


In another study by Akarsu et al., YMDD variant mutation was determined in 13 of 71 anti-HBe positive HBV carrier patients (18.3\%). L180M mutation was determined separately in 10 of 13 patients (76.9\%) (7).

Sayan et al., showed different mutations other than the ones detected in various studies in patients with naive chronic hepatitis B. These mutations varied as rtA194T, rtV214A, rtQ215S, rt233V, and rtN236T amino-acid transposition belonging to known lamivudine resistance mutations were not encountered (10).

In a study by Cao et al., YMDD mutation was determined in 18 of 53 patients $(33.9 \%)$ after lamivudine treatment. The mutation was determined in $15.1 \%$ of the patients at the end of the first year, and in $34 \%$ at the end of the second year. Four types of mutations were determined in the study: rtL180M/M204V, rtL180M/M204I, rtL180M, and rtM204I, rtL180M mutation is always accompanied by rtM204V mutation in gene C (100\%) (11).

In a study carried out by Locarnini et al., genotypic resistance was seen in $23 \%$ and $80 \%$ of patients receiving lamivudine treatment at the end of the first year and at the end of fifth year of treatment, respectively (12).

In our study, lamivudine resistance test was studied in a total of 172 patients receiving or not receiving lamivudine treatment. We determined mutation in 2 of 84 patients who were not receiving lamivudine treatment. On the other hand, there was mutation in 43 of 88 patients, who were receiving lamivudine treatment, in different periods. We concluded that in naive patients, resistance may develop spontaneously whereas in patients receiving treatment, resistance may be associated with drug-related mutation.

\section{References}

1. Lai CL, Ratziu V, Yuen MF, Poynard T. Viral Hepatitis B. Lancet. 2003;362:2089-2094.

2. Allen MI, Deslauriers $M$, Andrews CW, Tipples GA, Walters KA, Tyrrell DL. Identification and Characterization of mutations in hepatitis B virus resistant to lamivudine. Lamivudine Clinical Investigation Group. Hepatology. 1998;27(6):1670-1677.

3. Yamazhan T. Long term results in chronic hepatitis B treatment with antiviral. Tabak F, Balık I (eds). Viral Hepatitis 1nd ed. Istanbul,Istanbul Medikal Press. 2009, p:31.

4. Nafa S, Ahmed S, Tavan D, Pichoud C, Berby F, Stuyver L, Johnson M, Merle P, Abidi H, Trépo C, Zoulim F. Early detection of resistance by determination of hepatitis $B$ virus polymerase mutations in patients treated by lamivudine for chronic hepatitis B. Hepatology. 2000;32(5):1078-1088.

5. Melegari M, Scaqlioni PP, Wands JR. Hepatitis B virus mutants associated with 3TC and famciclovir administration are replication defective. Hepatology. 1998;27(2):628-633.

6. Koboyashi S, Ide T, Sata M. Detection of YMDD motif mutations in some lamivudine -untreated asymptomatic hepatitis B virus carriers. J Hepatol. 2001;34(4):584-586.

7. Akarsu M, Sengonul A, Tankurt E, Sayiner AA, Topalak O, Akpınar $\mathrm{H}$, Abacioglu $\mathrm{YH}$. YMDD motif variants in inactive hepatitis B carriers detected by Inno-Lipa HBV DR assay. J Gastroenterol Hepatol. 2006;21(12):1783-1788.

8. Matsuda M, Suzuki F, Suzuki Y, Tsubota A, Akuta N, Hosaka T, Someya T, Kobayashi M, Saitoh S, Arase Y, Satoh J, Kobayashi M, Ikeda K, Miyakawa Y, Kumada H. YMDD mutants in patients with chronic hepatitis $B$ before treatment are not selected by lamivudine. J Med Virol. 2004;74(2):361-366.

9. Tunçbilek $S$, Köse $S$, Elaldı A, Akman S. Lamivudine resistance in untreated chronic hepatitis B patients in Turkey. Turk J Gastroenterol. 2008;19(2):99-103.

10. Sayan M, Akhan SC, Meriç M. Naturally occuring aminoacid substitutions to nucleos(t)ide analogues in treatment naive Turkish patients with chronic hepatitis B. J Viral Hepat. 2010;17(1):23-27.

11. Cao XX, Li J, Qiu LM, Luo YW, Chen YH, Ran Y. Identification factors associated with YMDD mutation in patients with chronic hepatitis $B$ receiving lamivudine treatment. Zhonghua Gan Zang Bing Za Zhi. 2009;17(9):641-644.

12. Locarnini S. Primary resistance, multidrug resistance and crossresistance pathways in HBV as a consequence of treatment failure. Hepatol Int. 2008;2(2):147-151. 